\title{
Tissue and Serum Concentrations of Somatomedin-C/Insulin-Like Growth Factor I in Fetal Rats Made Growth Retarded by Uterine Artery Ligation
}

\author{
RITA A. VILEISIS AND A. JOSEPH D'ERCOLE \\ Departments of Pediatrics, Duke University, Durham, North Carolina 27710 and University of North Carolina, \\ Chapel Hill, North Carolina 27514
}

\begin{abstract}
ABSSIRAC "I. T' So sludy the role of somatomedin-( /insulinlike growth lactor I (Sm-C/IGF I) in felal growth, intrauterine growth retardation was induced by uterine artery ligation on day 17 of gestation in pregnant rats. letuses of the nonligated horns served as appropriately grown controls. ( )n day 21 of gestation, fetal serum, liver, and lung were obtained and analyzed for Sim-C/ICF I by radioimmunoassay. Serum insulin was determined by radioimmunoassay and serum glucose by a glucose oxidase methol. letal weight, serum concentrations of glucose, insulin and Sim-C/ICI I, and liver Sim-C / IGI I concentrations were reduced in fetuses from uterine artery ligated horns, as compared to those from nonligated control horns. letal weight was correlated with serum glucose $(r=0.703$; $p<0.001)$, liver Sim-C $/$ ICIF I $(r=0.682 ; p<0.001)$, and serum Sim-C $/$ ICFF I $(r=0.452 ; p<0.001)$. Stepwise linear regression demonstrated that these three factors in combination correlated highly wilh fetal weight $(r=0.836)$. No correlation was found for serum insulin or lung Sm- $\mathrm{Cy}$ IGI I and fetal weight. Serum insulin concentrations correlated with serum, but not liver, Sim-C/ICil I concentralions, making a direct effect of insulin on Sm-C/ICFI I synthesis appear unlikely. Ilowever, serum glucose concentrations correlated with liver $(r=0.404 ; p<0.001)$ and with serum Sim-C/IGII I $(r=0.308 ; p<0.002)$ concentrations, implicating felal glucose delivery in the regulation of Sm-C/IGI I synthesis. Taken together, these data suggest that Sm-C/ICII I synthesis in the fetus is influenced by nutrition and that Sim-C/ICI I plays a mediating role in the control of growth. (Pediatr Re's 20: 126-130, 1986)
\end{abstract}

\section{Abbreviations}

Sim-C, somatomedin C

IGF, insulin-like growth factor

$M S \Lambda$, multiplication stimulating activity

II $/(\mathbf{R}$, intrauterine growth retardation

RIA, radioimmunoassay

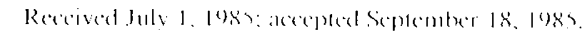

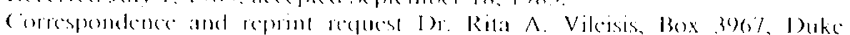

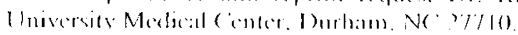

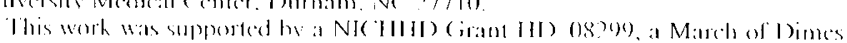

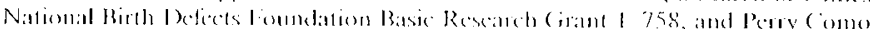

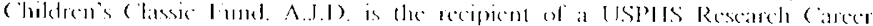

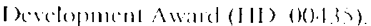

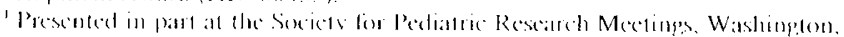
I). Mas losis.
The somatomedins, Sm-C/ICil: I and IGI: II/MSA, are peptide mitogens which share structural homology with insulin $(1,2)$. They ate thought to be critical to postnatal growth $(1,3)$, and more recently have been implicaled in fetal growth $(4,5)$. The factors that regulate somatomedins in the fetus are not fully defined, but do not appear to be the same as those which modulate somatomedins postnatally. Nutrition has a major regulatory influence on blood $\mathrm{Sm}-\mathrm{C} / \mathrm{I}$ (iv I concentrations in adult man (6-9) and in neonatal and postweanling rats $(10,11)$. In the fetus, however, the interrelationships between nutritional status, growth, and Sm-C / I if: I remain to be clarified.

In this study we employed the uterine artery ligation method of Wigglesworth (12) to induce fetal growth failure. Because nutritional deliciency secondary to impared transport of nutrients is a major component of the growth failure which occurs in this model (1.3), study of these growth retarded fetuses offers the opportunity to assess the physiological relationship of $\mathrm{Sm}-(\mathrm{C}$ ICil: I both to intrauterine growth and to nutritional deficiency. Tissue (liver and lung) and scrum Sm-( / I ill: I concentrations, as well as glucose and insulin concentrations were assessed in this study. We found that a reduction in glucose and Sm-C/le if: I concentrations in both liver and serum accounts in large part for the growth retardation of fetuses subjected to uterine antery ligation.

\section{MATIRIAIS ANI) METHIOISS}

Amimals and procedure. Pregnant Sprague-Dawley rats of known gestation weighing between 250 and 300 g were purchased from the (harles River laboratories (Wilmington, $M A$ ) and allowed free aceess to a stock dict. Rats were maled between 1600 and $0700 \mathrm{~h}$, and day 0 of pregnancy was considered to begin at $0700 \mathrm{~h}$. Intrauterine growth retardation was induced by the procedure of Wigglesworth (12). Briefly, on day 17 of gestation a laparotomy was performed under sterile conditions with ketamine anesthesia (20 mg intraperitencally). The uterus was exposed and a 3-() silk ligallure was placed around the uterine artery supplying the uterine horn with the larger number of fetuses. The valsculature of the opposite uterine horn was not touched and the feluses in the unperturbed horn served as controls. The uterus was returned to the abdominal eavity, the incision was closed, and the pregnancy was allowed to continuc until the day of sacrifice. Rats recovered ejuickly after surgery, usually within $3060 \mathrm{~min}$, and continued to gain weight at the rate of about 10 g $/$ day

()n day 21 of gestation under light ketamine anesthesia (10) mg intraperitoneally) a small incision was made in the utcrus (leaving the uteroplacental circulation intact) such that a fetal arm could be exposed withoul delivering the letus. $A$ deep incision was made in the axillary region and blood was collected 
by capillary action into a $100-\mu$ l glass tube. Serum was separated into three aliquots and stored at $-70^{\circ} \mathrm{C}$ until the time of analysis (within $8 \mathrm{wk}$ ). After exsanguination, each fetus was weighed. Liver and lung were dissected, blotted, immediately immersed in liquid nitrogen, and stored at $-70^{\circ} \mathrm{C}$ until analysis. A number indicating position within the uterine horn was assigned to each fetus (including resorbed fetuses), such that position 1 designated the fetus nearest the ovary.

Assays. Serum glucose concentration was assayed by the glucose oxidase method (14). Insulin was analyzed using a RIA kit purchased from Amersham (Arlington Heights, IL). If the volume of serum was inadequate for individual insulin analysis (after allotting serum for other assays), equal volumes of serum from littermates of the same uterine horn were pooled.

$\mathrm{Sm}-\mathrm{C} / \mathrm{IGF}$ I was estimated in serum by RIA using a published modification (15) of the original reported procedure (16). Use of this assay for rat serum has previously been validated $(17,18)$. Prior to assay, all sera were diluted $1: 1$ with glycine-glycine $\mathrm{HCl}$ buffer (ionic strength $=0.1$ ) in order to achieve a final $\mathrm{pH}$ of 3.6 and incubated at $37^{\circ} \mathrm{C}$ for $24 \mathrm{~h}$. This acid incubation procedure maximizes the amount of measurable, immunoreactive $\mathrm{Sm}-\mathrm{C} /$ IGF I by antigenic sites of Sm-C/IGF I free from binding proteins (19). Neutralization of acid-incubated sera was accomplished with $1 \mathrm{M} \mathrm{NaOH}$. Tissue (liver and lung) Sm-C/IGF I concentrations were estimated by the same assay after extraction using a validated modification (20) of the original reported procedure (18). In several cases, lung tissues were pooled with littermates of the same horn prior to analysis. Results were calculated using a human serum standard (15) and expressed as $\mathrm{U} / \mathrm{ml}$ for serum and $\mathrm{U} / \mathrm{g}$ wet weight for tissues. Adult rat serum is 7 to 15 -fold more potent than adult human serum in this assay (18).

Statistics. Statistical analysis was initially performed by analysis of variance to determine the influence of uterine artery ligation and uterine position on the measured variables. Thereafter the unpaired $t$ test was performed to test differences between individual fetal variables in ligated and control horns at the same uterine position.

Since pooling of samples was required for determination of serum insulin and lung Sm-C/IGF I concentrations, differences between horn means (rather than individual fetal concentrations) were assessed. Finally, correlation coefficients and stepwise linear regressions were performed among variables using Statistical Analysis Systems (Cary, NC) programs. Statistical significance is assigned to $p$ values $<0.05$.

\section{RESULTS}

A total of 28 pregnant rats underwent uterine artery ligation. Thirteen rats were excluded from the study because uterine artery ligation resulted in no viable fetuses in the ligated horn. As expected with this procedure, the number of fetuses in each uterine artery ligated horn was reduced $(2.73 \pm 0.31$, mean \pm SEM; $n=15)$ compared to the control horns $(4.13 \pm 0.34 ; n=$ $15 ; p<0.05)$. A total of 101 viable fetuses resulted, 90 of which were distributed in uterine positions $1-4$. Fetal weight was reduced in the ligated horn, whether analyzed as individual fetal weights $(3.02 \pm 0.10 \mathrm{~g}, n=43)$ or as litter mean $(3.03 \pm 0.14 \mathrm{~g}$, $n=15)$ compared to fetuses in the control horn (4.32 \pm 0.09 for individual fetuses, $n=58 ; p<0.0001 ; 4.41 \pm 0.17$ for litter means, $n=15, p<0.0001$, respectively).

As initially reported by Wigglesworth (12), the fetuses farthest from the ligation exhibited the least degree of growth retardation, and when analyzed by analysis of variance, position had a significant $(p<0.03)$ influence on fetal weight. Analysis of variance also showed that fetal weight, serum and liver Sm-C/ IGF I, and serum glucose concentrations were reduced in the fetuses of the uterine artery ligated horn $(p<0.0001)$. Although this analysis did not indicate that uterine position had a significant influence on any variable other than weight, we chose to further analyze the data by comparing fetuses at each uterine position of ligated and nonligated horns. The strong relationship of fetal size and uterine position makes this approach intuitively appealing, and this more conservative test of significance is less likely to yield a type I error (false-positive). At each position, fetal weight, serum glucose concentration, liver and serum Sm$\mathrm{C} / \mathrm{IGF}$ I concentrations were significantly reduced in the IUGR fetuses, compared to their position-matched appropriately grown control counterparts (Table 1).

Because insufficient quantities of sera necessitated pooling of serum from fetuses in the same horn to perform insulin determinations, comparison of insulin concentrations was performed by $t$ test on the means of each horn. Insulin concentrations were significantly lower in the IUGR fetuses $(64 \pm 12 \mu \mathrm{U} / \mathrm{ml})$ than in control fetuses $(131 \pm 18 \mu \mathrm{U} / \mathrm{ml}, p<0.01)$. Lung Sm-C/IGF I concentrations did not differ between fetuses from control and ligated horns, $0.28 \pm 0.03$ and $0.24 \pm 0.03 \mathrm{U} / \mathrm{gm}$, respectively.

Fetal weight correlated positively with serum glucose concentrations $(r=0.703 ; n=97 ; p<0.001)$, liver Sm-C/IGF I concentration $(r=0.682 ; n=101 ; p<0.001$; Fig. 1$)$, and serum Sm-C/IGF I $(r=0.452 ; n=101 ; p<0.001)$ when all fetuses were considered together. Stepwise linear regression demonstrated that these three factors in combination correlated very highly with fetal weight $(r=0.836)$. Significant correlations were not found for mean horn insulin concentrations $(r=0.378 ; n==$ 22 ) or for mean horn lung Sm-C/IGF I concentrations ( $r=0.256$; $n=30)$ and fetal weight.

Other correlations of possible biologic relevance include a significant relationship between serum glucose and liver $\mathrm{Sm}-\mathrm{C} /$

Table 1. Fetal wt, serum glucose, liver, and serum Sm-C/IGF I concentrations (mean \pm SEM) at each uterine position in control and IUGR fetuses*

\begin{tabular}{|c|c|c|c|c|}
\hline & \multicolumn{4}{|c|}{ Uterine position } \\
\hline & $1(n)$ & $2(n)$ & $3(n)$ & $4(n)$ \\
\hline \multicolumn{5}{|l|}{$\mathrm{Wt} \dagger(\mathrm{g})$} \\
\hline Control & $4.41 \pm 0.19(13)$ & $4.44 \pm 0.18(15)$ & $4.37 \pm 0.18(14)$ & $3.46 \pm 0.45(10)$ \\
\hline IUGR & $3.15 \pm 0.17(15)$ & $2.95 \pm 0.24(10)$ & $2.84 \pm 0.17(8)$ & $2.62 \pm 0.10(5)$ \\
\hline \multicolumn{5}{|c|}{ Serum glucose $(\mathrm{mg} / \mathrm{dl})$} \\
\hline Control & $66 \pm 3(13)$ & $64 \pm 7(14)$ & $71 \pm 9(13)$ & $67 \pm 8(10)$ \\
\hline IUGR & $41 \pm 3(15)$ & $30 \pm 5(9)$ & $34 \pm 5(8)$ & $37 \pm 8(5)$ \\
\hline \multicolumn{5}{|c|}{ Liver Sm-C/IGF I (U/g) } \\
\hline Control & $0.29 \pm 0.03(13)$ & $0.30 \pm 0.03(15)$ & $0.32 \pm 0.03(14)$ & $0.22 \pm 0.02(10)$ \\
\hline IUGR & $0.20 \pm 0.02(15)$ & $0.18 \pm 0.02(10)$ & $0.15 \pm 0.02(8)$ & $0.12 \pm 0.03(5)$ \\
\hline \multicolumn{5}{|c|}{ Serum Sm-C/IGF I (U/ml) } \\
\hline Control & $1.53 \pm 0.05(13)$ & $1.53 \pm 0.08(15)$ & $1.49 \pm 0.11(14)$ & $1.34 \pm 0.07(10)$ \\
\hline IUGR & $1.08 \pm 0.10(15)$ & $0.95 \pm 0.10(10)$ & $0.89 \pm 0.16(8)$ & $0.79 \pm 0.26(5)$ \\
\hline
\end{tabular}

* All comparisons between IUGR and control are different at $p<0.05$.

+ After exsanguination. 


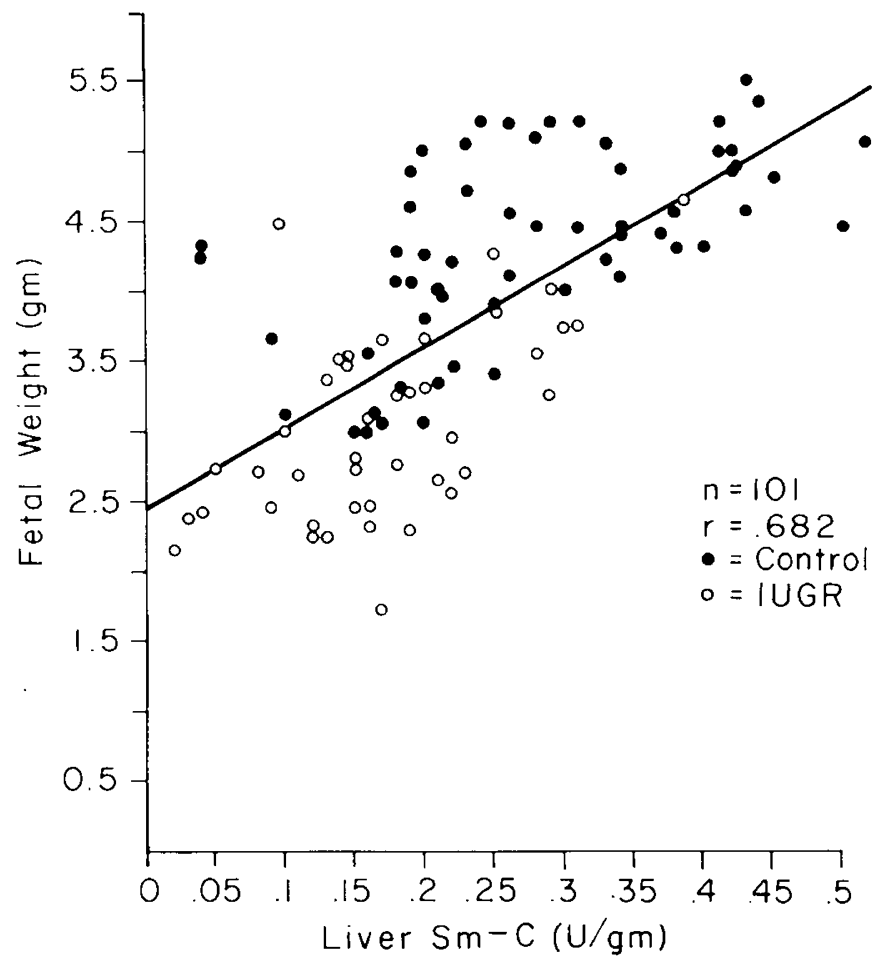

Fig. 1. Liver Sm-C/IGF I concentration in IUGR $(O)$ and control (O) fetal rats compared to fetal weight $(r=0.682 ; n=101 ; p<0.001)$. Mean ( \pm SEM) liver Sm-C/IGF I concentrations are $0.17 \pm 0.01 \mathrm{U} / \mathrm{g}(n$ $=43)$ for IUGR fetuses and $0.27 \pm 0.02(n=58)$ for control fetuses $(p$ $<0.001)$. Serum Sm-C/IGF I in the same fetuses are $1.01 \pm 0.06 \mathrm{U} / \mathrm{ml}$ and $1.45 \pm 0.04$, respectively $(p<0.001)$.

IGF I concentrations $(r=0.308 ; n=101 ; p<0.002)$. In addition, serum Sm-C/IGF I correlated with liver Sm-C/IGF I $(r=0.361$; $n=101 ; p<0.001)$. We also attempted to correlate litter mean insulin concentrations with litter mean serum and with liver Sm$\mathrm{C} / \mathrm{IGF}$ I concentrations. Although there is a significant relationship between insulin and serum Sm-C/IGF I ( $r=0.499 ; n=22$; $p<0.02)$, there is none between insulin and liver Sm-C/IGF I $(r=0.400 ; n=22)$.

\section{DISCUSSION}

Our findings that both liver and serum Sm-C/IGF I concentrations are reduced in IUGR fetuses and that both measures correlate with fetal weight suggest a mediating role for $\mathrm{Sm}-\mathrm{C} /$ IGF I in the control of fetal growth. These results are consistent with those of DePrins et al. (21) who found decreased serum concentrations of somatomedin bioactivity in fetal rats made growth retarded by uterine artery ligation. They also reported a significant correlation between the bioactive somatomedin concentrations and fetal body size. Unlike the original report of Wigglesworth (12) and this study, DePrins et al. (21) did not find that fetal size was influenced by the proximity of the conceptus to the site of uterine artery ligation. Subtle differences in techniques may explain this discrepancy.

The RIA used in this study employs an antibody directed against human Sm-C/IGF I and has been validated for the estimation of this peptide in rats $(17,18)$. Rat homologues of human somatomedins (Sm-C/IGF I and IGF II) have been purified. A peptide purified from adult rat serum bears marked homology to Sm-C/IGF I (22) and has been reported to be 30 $40 \%$ as potent as Sm-C/IGF I in competing for binding to this antibody (23); MSA, the rat homologue of IGF II (24), crossreacts minimally with our antibody $(1.2 \%$ for MSA III- 2 and $0.025 \%$ for MSA II-1) (25). When this RIA is used to measure specimens from rats, it is likely to underestimate rat $\mathrm{Sm}-\mathrm{C} / \mathrm{IGF}$
I by 2.5 to 3.3 -fold and to detect MSA only when it is present in very high concentrations. In the fetal rat, however, serum SmC/IGF I concentrations are low compared to those of MSA (23, 26), and, although unlikely to be a significant factor, it remains possible that the immunoactivity reported in this study in part reflects cross-activity with MSA. Precise determination of the quantities of Sm-C/IGF I and MSA in fetal rat sera awaits simultaneous studies of the same sera with antibodies directed against both peptides and/or use of antibodies with no crossreactivity.

Although not directly addressed in the study, it is reasonable to suspect that fetal nutritional deficiency occurring from uterine artery ligation (13) leads to the decrease in Sm-C/IGF I concentrations and, in turn, results in a decrease in fetal growth. Serum $\mathrm{Sm}-\mathrm{C} / \mathrm{IGF} \mathrm{I}$ in the postnatal rat and in man has been shown to be highly dependent on nutritional status $(1,6-10)$. In the postweanling rat, we have shown that both energy and protein intake determined serum Sm-C/IGF I and growth (11). In man, serum $\mathrm{Sm}-\mathrm{C} / \mathrm{IGF} \mathrm{I}$ is reduced dramatically by fasting and returns to normal with refeeding (6). The rate of return of serum Sm-C/ IGF I concentrations from low basal fasting levels to normal is dependent on the quality of the diet which is refed (7-9).

Inadequate nutrient transfer to the fetus may account, in large part, for the growth failure resulting from uterine artery ligation. In the Wigglesworth (12) model, the reduction in uteroplacental blood flow is associated with a decrease in placental transfer of maternally administered analogues of glucose and amino acids (13). In spontaneous growth retardation occurring in fetal guinea pigs, Saintonge and Rosso (27) also demonstrated an association between reduced placental blood flow and a reduction in the transfer of both amino acid and glucose analogues. Studies utilizing in situ perfusion of the guinea pig placenta substantiate the conclusion that the transfer of these analogues to the fetus is dependent on placental blood flow $(28,29)$. Placental hypoxia, which probably occurs in uteroplacental insufficiency, per se may result in decreased glucose and amino acid transport (30, $31)$. Fetal oxygen uptake is also uterine blood flow dependent under conditions of severe uterine blood flow restriction (32). Thus, fetal substrate deprivation is a major component of the pathophysiology induced by uterine artery ligation.

The strongest correlation in this study is that of glucose concentrations and fetal size. This is not surprising given that glucose has long been implicated as the major fetal metabolic fuel, both for maintenance of fetal oxidation and formation of new tissue (33). States of pathologic fetal growth, either overgrowth or undergrowth, have a direct positive relationship with fetal glucose uptake (33-35). Fetal glucose uptake accounts for a large fraction of the total oxygen consumption and serves as a substrate source for fetal glycogen and lipid synthesis $(36,37)$. Maternal hyperglycemia results in augmentation of both of these biosynthetic functions, even in cases of flow restricted intrauterine growth retardation $(38,39)$. Our finding of a correlation between glucose and $\mathrm{Sm}-\mathrm{C} / \mathrm{IGF} \mathrm{I}$ concentrations in liver and serum suggests a role for nutrient availability (specifically of glucose) in the control of fetal Sm-C/IGF I production and/or release.

Fetal hypoinsulinemia has been suggested as an etiology of fetal growth retardation (40). Analysis of our data has failed to establish a relationship between fetal weight and insulin concentrations. In addition, investigations by others have not led to conclusive evidence that insulin is the primary controller of fetal anabolism $(4,41)$. It may be that insulin in the fetus serves "to maintain a favorable homeostatic environment" (4), or alternately insulin may stimulate fetal somatomedin production. Both fetal rabbits and pigs respond to hyperinsulinemia with elevation of somatomedin bioactivity (42-44). However, our observations of an association between insulin and serum SmC/IGF I, but not with liver Sm-C/IGF I, do not support a strong direct role for insulin in the control of Sm-C/IGF I synthesis. We speculate that insulin does not directly influence Sm-C/IGF I, but that substrate (possibly glucose) concentrations influence both insulin and somatomedin homeostasis. 
The somatomedins are synthesized in many fetal tissues (45) and are thought to act in an autocrine and/or paracrine fashion, i.e. they exert their biologic activity on their cells of origin or on cells near their sites of synthesis (18). Because the liver is considered to be a major site of somatomedin synthesis $(1,2)$, it is not surprising that liver Sm-C/IGF I concentrations correlate better with fetal weight than do serum Sm-C/IGF I concentrations. The significant correlations of liver Sm-C/IGF I with serum SmC/IGF I concentrations support the hypothesis that the fetal liver is a major source of somatomedin activity in the circulation. Because of its location as the first organ to be exposed to changes in nutrient flux (whether they be from the placenta prenatally or from the gut postnatally), the liver is likely to be profoundly influenced by nutritional status. Our finding that there is a reduction in liver, but not in lung, of Sm-C/IGF I concentrations associated with uterine artery ligation is consistent with this hypothesis. This is also consistent with our previous findings that there is a greater reduction of liver Sm-C/IGF I than of lung or kidney Sm-C/IGF I in calorically deprived adult rats (46). That lung $\mathrm{Sm}-\mathrm{C} / \mathrm{IGF}$ I concentrations are not reduced in IUGR fetuses and do not correlate with fetal weight suggest that in this organ Sm-C/IGF I is regulated differently (by a different mechanism or by the same mechanism but to a much lesser degree) than liver Sm-C/IGF I.

Evidence for an important role for Sm-C/IGF I in fetal development comes from multiple sources $(4,5)$. Sm-C/IGF I is a potent mitogen for a variety of cultured fetal cells $(4,5)$ including those derived from rodents $(47,48)$. Fetal tissues $(49,50)$, including those derived from the rat (51), possess type I insulinlike growth factor receptors, i.e. plasma membrane receptors which have a higher affinity for Sm-C/IGF I than for IGF II/ MSA (52). Despite its relatively low circulating concentrations, plasma Sm-C/IGF I concentrations in cord blood correlate well with birth size $(4,5)$. Sm-C/IGF I is capable of potent anabolic actions other than its mitogenic effect. It can stimulate amino acid uptake in cultured fibroblasts, including those derived from the fetus and neonate (53). Sm-C/IGF I is more potent than insulin in the stimulation of glycogen synthesis in cultured fetal rat hepatocytes (54), suggesting a specific role for Sm-C/IGF I in the rat fetus. In this regard, MSA appears to have less than $5 \%$ of the potency of Sm-C/IGF I (55). Although it has been suggested that MSA (rat IGF II) is the relevant somatomedin for the rat fetus (56), it is likely that Sm-C/IGF I also has an important role.

Acknowledgments. The authors thank Drs. Majorie Svoboda and Judson K. Van Wyk for providing the purified Sm-C/IGF I used in this study, Mrs. Folu Moses for preparing the manuscript, and Ms. Gwen Clark for technical assistance.

\section{REFERENCES}

1. Van Wyk JJ 1984 The somatomedins: biological actions and physiologic control mechanisms. In: $\mathrm{Li} \mathrm{CH}$ (cd) Hormonal Proteins and Peptides. Academic Press. Inc. New York, pp 81-125

2. Zapf J. Schmid C. Frocsch EB 1984 Biological and immunological properties of insulin-like growth factors (IGF) I and II In: Daughaday WH (ed) Clinics in Endocrinology and Metabolism, Vol 13. Tissue Growth Factors. WB Saunders Company Ltd. East Sussex. UK. pp 3-30

3. Daughaday WH 1981 Growth hormone and the somatomedins. In: Daughaday WH (ed) Endocrine Control of Growth. Elsevier-North Holland. New York. pp $1-24$

4. Underwood LE, D’Ercole AJ 1984 Insulin and insulin-like growth factors/ somatomedins in fetal and neonatal development In: Daughaday WH (ed) Clinics in Endocrinology and Mctabolism, Vol 13. Tissue Growth Factors. WB Saunders Company Ltd. East Sussex, UK, pp 69-89

5. D'Ercole AJ. Underwood LE 1985 Regulation of fetal growth by hormones and growth factors In: Falkner F. Tanner JM (eds) Human Growth, vol 1 Plenum Publishing Co, NY. pp 327-338

6. Clemmons DR Klibanski A Underwood LE McArthur JW Ridgway EC Beitins IZ. Van Wyk JJ 1981 Reduction of plasma immunoreactive somatomedin $C$ during fasting in humans. J Clin Endocrinol Metab 53:12471250

7. Isley WL. Underwood LE, Clemmons DR 1983 Dietary components that regulate serum somatomedin-C concentrations in humans. J Clin Invest $71: 175-182$
8. Isley WL, Underwood LE, Clemmons DR 1984 Changes in plasma somatomedin- $C$ in response to ingestion of diets with variable protein and energy content. JPEN 8:407-411

9. Clemmons DR, Seek M, Underwood LE 1985 Supplementary essential amino acids augment the somatomedin-C/insulin-like growth factor I response to refeeding after fasting. Metabolism 34:391-395

10. Macs M, Underwood LE, Gérard G, Ketelslegers JM 1984 Relationship between plasma somatomedin- $\mathrm{C}$ and liver somatogenic binding sites in neonatal rats during malnutrition and after short and long term refeeding. Endocrinology 115:786-792

11. Prewitt TE, D'Ercole AJ, Switzer BR, Van Wyk JJ 1982 The relationship of serum immunoreactive somatomedin- $C$ to dietary protein and energy in the growing rat. J Nutr 112:144-150

12. Wigglesworth JS 1964 Experimental growth retardation in the foetal rat. J Pathol Bacteriol 88:1-13

13. Nitzan M. Orloff S, Shulman JD 1979 Placental transfer of analogs of glucose and amino acids in experimental intrauterine growth retardation. Pediatr Res 13:100-103

14. Raabo E, Terkildsen TC 1960 On the enzymatic determination of blood glucose. Scand J Clin Lab Invest 12:402-407

15. Copeland KC. Underwood LE, Van Wyk JJ 1980 Induction of immunoreactive somatomedin-C in human serum by growth hormone: Dose response relationships and effect on chromatographic profiles. J Clin Endocrinol Metab 50:690-697

16. Furlanetto RW, Underwood LE, Van Wyk JJ, D'Ercole AJ 1977 Estimation of somatomedin-C levels in normals and patients with pituitary disease by radioimmunoassay. J Clin Invest 60:648-657

17. Hurlcy TW, D'Ercole AJ, Handwerger S, Underwood LE, Furlannetto RW, Fellows RE 1977 Ovine placental lactogen induces somatomedin: a possiblc role in fetal growth. Endocrinology 101:1635-1638

18. D'Ercole AJ, Stiles AD, Underwood LE 1984 Tissue concentrations of somatomedin-C: further evidence for multiple sites of synthesis and paracrine or autocrine mechanisms of action. Proc Natl Acad Sci (USA) 81:935-939

19. Chatelain PG, Van Wyk JJ, Copeland KC, Blethen SL. Underwood LE 1983 Effect of in vitro action of serum proteases or exposure to acid on measurablc immunoreactive somatomedin-C in serum. J Clin Endocrinol Metab 56:376-383

20. D’Ercole AJ, Underwood Le 1985 Estimation of tissue concentrations of somatomedin-C/insulin-like growth factor I (Sm-C/IGF I) In: Barnes D and Sirbasku DA (eds) Methods in Enzymology (in press)

21. DePrins FA, Hill DJ, Fekete M, Robsen DJ, Fieller NRJ, Van Assche FA, Milner RDG 1984 Reduced plasma somatomedin activity and costal cartilage sulfate incorporation activity during experimental growth retardation in the fetal rat. Pediatr Res 18:1100-1104

22. Rubin JS, Mariz I, Jacobs JW. Daughaday WH, Bradshaw RA 1982 Isolation and partial sequence analysis of rat basic somatomedin. Endocrinology 110:734-740

23. Daughaday WH, Parker KA, Borowsky S, Trivedi B, Kapadia M 1982 Measurement of somatomedin-related peptides in fetal, neonatal, and maternal rat serum by insulin-like growth factor (IGF) I radioimmunoassay, IGF II radioreccptor assay (RRA), and multiplication-stimulating activity RRA after acid-ethanol extraction. Endocrinology 1 10:575-581

24. Marquardt H. Todaro GJ, Henderson LE. Oroszlan S 1981 Purification and primary structure of a polypeptide with multiplication-stimulating activity (MSA) from rat liver cell cultures: Homology with human insulin-like growth factor II (IGF II). J Biol Chem 256:6859-6865

25. Van Wyk JJ, Svoboda ME, Underwood LE 1980 Evidence from radioligand assays that somatomedin-C and insulin-like growth factor I are similar to each other and different from other somatomedins. J Clin Endocrinol Metab 50:206-208

26. Moses AC, Nissley SP. Short PA, Rechler MM, White BM, Knight AB, Higa $\mathrm{OZ} 1980$ Elevated levels of multiplication-stimulating activity, an insulinlike growth factor, in fetal rat serum. Proc Natl Acad Sci (USA) 77:36493653

27. Saintonge J, Rosso P 1981 Placental blood flow and transfer of nutrient analogs in large, average, and small guinca pig littermates. Pediatr Res 15:152-156

28. Joyce J. Young M 1974 A comparison of the cffect of a reduction in maternal blood flow on the placental transfer of glucose and amino nitrogen from mother to foetus. J Physiol (Lond) 239:5P-6P

29. Krauer F, Joyce J, Young M 1973 The influence of high maternal plasma glucose levels, and maternal blood flow on the placental transfer of glucose in the guinea pig. Diabetologia 9:453-456

30. Lumley JM, Wood C 1967 Influence of hypoxia on glucose transport across the human placenta. Nature 216:403-404

31. Longo LD, Yuen P. Gusseck DJ 1973 Anacrobic, glycogen dependent transport of amino acids by the placenta. Nature 243:531-533

32. Wilkening RB, Meschia G 1983 Fetal oxygen uptake, oxygenation, and acidbase balance as a function of uterine blood flow. Am J Physiol 244:H749 $\mathrm{H} 755$

33. Battaglia FC, Meschia G 1978 Principal substrates of fetal metabolism. Physiol Rev 58:499-525

34. Simmons MA. Jones MD, Battaglia FC. Meschia G 1978 Insulin effect on fetal glucose utilization. Pediatr Res 12:90-92

35. Meschia G 1978 Substrate availability and fetal growth. In: Naftolin F (ed) Abnormal Fetal Growth: Biological Bases and Consequences. Dahlem Konferenzen, Berlin, pp 221-228

36. Hay WH 1984 Fetal and neonatal glucose homeostasis and their relation to the small for gestational agc infant. Semin Perinatol 8:101-116 
37. Ballard FJ, Hanson RW 1967 Changes in lipid synthesis in rat liver during development. Biochem J 102:952-958

38. Oh W D'Amodio MD. Yap LL. Hohenauer L 1970 Carbohydrate metabolism in experimental intrauterine growth retardation in rats. Am J Obstet Gynecol 108:415-421

39. Vileisis RA. Oh W 1983 Effect of increased substrate availability on fatty acid synthesis in the growth retarded fetus. Metabolism 32:90-94

40. Hill DE 1978 Effect of insulin on fetal growth. Semin Perinatol 2:319-328

41. Stangenberg M. Eklöf A-Ch. Dahlquist G. Persson B 1981 Lack of effect on body weight and content of nitrogen and fat after insulin administration to fetal rats. Biol Neonate 40:240-245

42. Hill DJ, Milner RDG 1980 Increased somatomedin and cartilage metabolic activity in rabbit fetuses injected with insulin in utero. Diabetologia 19:143147

43. Spencer GSG Garssen GJ, Colenbrander B, MacDonald AA, Bevers MM 1983 Glucose, growth hormone, somatomedin, cortisol and ACTH changes in the plasma of unanaesthetized pig foetuses following intravenous insulin administration in utcro. Acta Endocrinol 104:240-245

44. Spencer GSG Hill DJ, Garssen GJ, MacDonald AA. Colenbrander B 1983 Somatomedin activity and growth hormone levels in body fluids of the fetal pig: effects of chronic hyperinsulinemia. J Endocrinol 96:107-114

45. D'Ercole AJ, Applewhite GT, Underwood LE 1980 Evidence that somatomedin is synthesized by multiple tissues in the fetus. Develop Biol 75:315-328

46. Russell WD. D’Ercole AJ. Underwood LE 1985 Somatomedin-C/insulin-like growth factor I during liver regeneration in the rat. Am J Physiol 248:E618E623

47. Sara VR. Hall K. Ottosson-Secberger A and Wetterberg L 1980 The rolc of the somatomedins in fetal growth. In: Cumming IA, Funder JW, Mendelsohn FAO (eds) Endocrinology 1980. Elsevier/North Holland, Inc., New York, pp 453-456

48. Lenoir D. Honegger P 1983 Insulin-like growth factor I (IGF I) stimulates DNA synthesis in fetal rat brain cell cultures. Dev Brain Res 7:205-213

49. Sara VR, Hall K, Misaki M. Fryklund L, Christensen N, Wetterberg L 1983 Ontogenesis of somatomedin and insulin receptors in the human fetus. $J$ Clin Invest $71: 1084-1094$

50. Grizzard JD. D'Ercole AJ, Wilkins JR, Moats-Staats BM, Williams RW 1984 Affinity labeled somatomedin-C receptors and binding proteins from the human fetus. J Clin Endocrinol Metab 58:535-543

51. Pilistine SJ, Moses AC, Munro HN 1984 Insulin-like growth factors receptors in rat placental membranes. Endocrinology 115:1060-1065

52. Massague J.Czech MP 1982 The subunit structures of two distinct receptors for insulin-like growth factors I and II and their relationship to the insulin receptor. J Biol Chem 257:5038-5045

53. Kaplowitz PB, D'Ercole AJ, Underwood LE Van Wyk JJ 1984 Stimulation by somatomedin-C of aminoisobutyric acid (AIB) uptake in human fibroblasts: A possible test for cellular responsiveness to somatomedin. J Clin Endocrinol Metab 58:176-181

54. Freemark M, D'Ercole AJ, Handwerger S 1985 Somatomedin-C stimulates glycogen synthesis in fetal rat hepatocytes. Endocrinology 116:2574-2582

55. Freemark M, D'Ercole AJ, Handwerger S 1985 Glycogenic effects of SmC MSA, and EGF in fetal rat hepatocytes. Pediatr Res 19:619(Abstr 98)

56. Adams SO, Nissley SP, Handwerger S, Rechler MM 1983 Developmental patterns of insulin-like growth factor I and II synthesis and regulation in rat fibroblasts. Nature 302:150-153 